\title{
Paleoceanography and Paleobiogeography Patterns of the Turonian-Campanian Foraminifers from the Abderaz Formation, North Eastern Iran
}

\author{
Meysam Shafiee Ardestani ${ }^{* *}$, Mohammad Vahidinia', Abbas Sadeghi \\ ${ }^{1}$ Department of Geology, Faculty of Science, Ferdowsi University of Mashhad, Mashhad, Iran \\ ${ }^{2}$ Department of Geology, Faculty of Science, Shahid Beheshti University, Tehran, Iran \\ Email: "Meysam.shafieeardestani@stu.um.ac.ir
}

Received October 5, 2012; revised November 7, 2012; accepted December 9, 2012

\begin{abstract}
In this research, the Turonian-early Campanian sedimentary succession of the Abderaz Formation with 510 m thick (comprising: light grey shale and marls) was studied in the type section in eastern Kopeh-Dagh basin. The statistical analysis of the morphotype groups of the identified planktonic foraminifers shows that most of them are shallow water forms (SWF) and deep water forms (DWF). The high planktonic to benthic ratio indicates particular oligotrophic conditions and sedimentation in relatively deeper zones of a marine environment. The salinity of sea water during Coniacian was in the minimum level, whereas it reached maximum in Coniacian-Santonian boundary. Comparing Planktonic assemblages from the study formation with those from the Cretaceous biogeographical provinces reflects a close relationship between the identified species and the planktonic forms of the Tethyan provinces.
\end{abstract}

Keywords: Kopeh-Dagh Basin; Abderaz Formation; Planktonic Foraminifer; Morphotype; Sea Level Change; Palaeosalinity

\section{Introduction}

Paleobathymetry is a significant environmental aspect of paleoceanography and paleoclimate reconstructions. It is mostly important in modeling of the uplift and subsidence history of sedimentary basins. Additionally, much attention is being paid to the construction of sea-level curves. The distribution of foraminifers in the modern oceans is basic for the interpretation of fossil morphotypes. Many species are temperature-dependent, particularly those that are restricted to temperate and warm waters. Warmer-water species are usually large, thickwalled complex morphotypes, and populations are characterized by high diversity. Species in waters with lower temperatures have globular chambers and their populations are rather regular. The life-cycle is to be accomplished with a concomitant depth migration [1]. The depth-range is different for every group, and it was suggested that the control is maintained by density. One of the main aims of this research is to analyse the geometric architecture of the tests of planktonic foraminifers, as well as the planktonic to benthic ratio, in order to reconstruct the sea level changes during the past. Diverse methods were used to obtain different palaeobathymetric

*Corresponding author. data. Shafiee Ardestani et al. (2008) [1] applied the Hart method [2] to study and analyze the palaeobathymetry aspects of the foraminiferas within the sediments of the Abderaz Formation in the type section. In this paper, the sea level changes are reconstructed on the basis of [3] three swarming morphotypes (ESF, SWF, DWF), and planktonic to benthic foraminifera ratios. Many expert micropalaeontologists considered this ratio in measurements of the sedimentation depth [4]. Initial researches about these analysis began between 1951 and 1955 [5,6], by determining the relationship between water depth and planktonic to benthic foraminifera ratios. In this research we use several different morphotype groups, especially deep water forms, to estimate the sea level changes in the study succession. The analysis of the identified planktonic foraminifer groups (Hedbergella and Whiteinella) within the study sediments is also useful in measuring paleosalinity fluctuations $[7,8]$. Finally we compared the frequency and dispersal of all cool and warm water fauna from the study sediments with those with Tethyan province affinities.

\section{The Locality of the Study Area}

The Kopeh Dagh sedimentary basin formed after the Middle Triassic orogeny in northeast Iran. The basin started 
to sink along the major faults aligned approximately NW-SE. The Cretaceous sediments in the Kopeh-Dagh Basin are divided into nine different formations, composed mainly of sandstones, conglomerates, mudstones, limestones and dolomites with minor amounts of evaporates. The thickness of these sediments is normally more than $4000 \mathrm{~m}$, but only about $2500 \mathrm{~m}$ in the eastern part of the basin. Abderaz Formation is a major formation in Kopeh-Dagh basin at northeastern of Iran with upper Cretaceous age. The type section of the Abderaz Formation is situated in northeast of Mashhad on the main Mashhad-Sarakhs road, approximately 1 kilometre from Muzduran $\left(60^{\circ} 33^{\prime} 00^{\prime \prime} \mathrm{E}, 36^{\circ} 10^{\prime} 40^{\prime \prime} \mathrm{N}\right)$ (Figure 1). The late Cretaceous Abderaz Formation, in the type section in north eastern Iran, consists of a $510 \mathrm{~m}$ thick succession comprising of: 1-thin bedded, light grey marl (20 m), 2-thin bedded, grey shale $(140 \mathrm{~m}), 3$-thin bedded, grey to yellowish marl $(80 \mathrm{~m}), 4$-thin bedded, light green marl (30 m), 5-thin bedded, light grey shale (20 m), 6-thick bedded, bluish limestone (30 m), 7-thin bedded, light grey marl (10 m), 8-yellowish chalk limestone $(30 \mathrm{~m}), 9$-light grey marl $(90 \mathrm{~m}), 10$-light grey shale $(10 \mathrm{~m})$ and 11 - thick bedded chalky limestone (50 $\mathrm{m})$ (Figure 2). The dark olive shales in the basal part of the Abderaz Formation lay disconformably on the Aitamir Formation, whereas the chalky limestones of the upper parts are conformably covered by the Abtalkh Formation. Although it was named after the village of Abderaz, the Abderaz Formation is located in Mazdavand [9]. The Abderaz Formation in the type section has a bad land pattern, consisting of marls and shales with low permeability. The study section of the Abderaz Formation heads in a North-Eastern direction with an angle of $84^{\circ}$, while the layers extend in a north-western to south-eastern trend.

\section{Methods and Materials}

A total number of 137 samples were gathered from the 510 m thick succession of the Abderaz Formation. How-

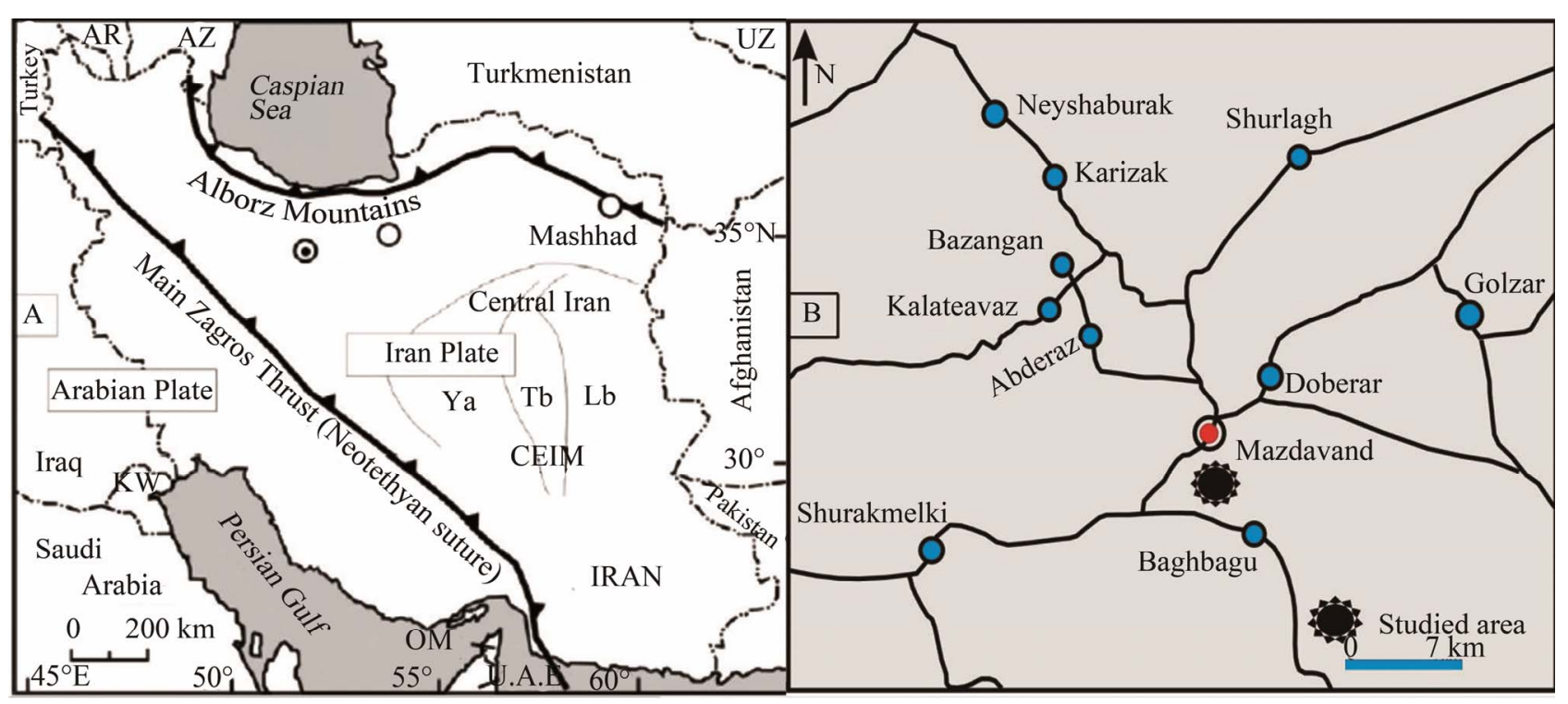

Figure 1. (A) Structural geology and geography map of Iran showing the main sutures, structural units and geographic areas (redrawn from Ghasemi-Nejad et al., 2012). AR: Armenia, AZ: Azerbaijan, UZ: Uzbekistan, Yb: Yazd Block, Tb: Tabas Block, Lb: Lut Block, CEIM: Central-East Iranian microcontinent, OM: Oman, UAE: United Arab Emirates, KW: Kuwait. (B) Location map of the Abderaz Formation at Mazdavand (type) section, Northeastern Iran.

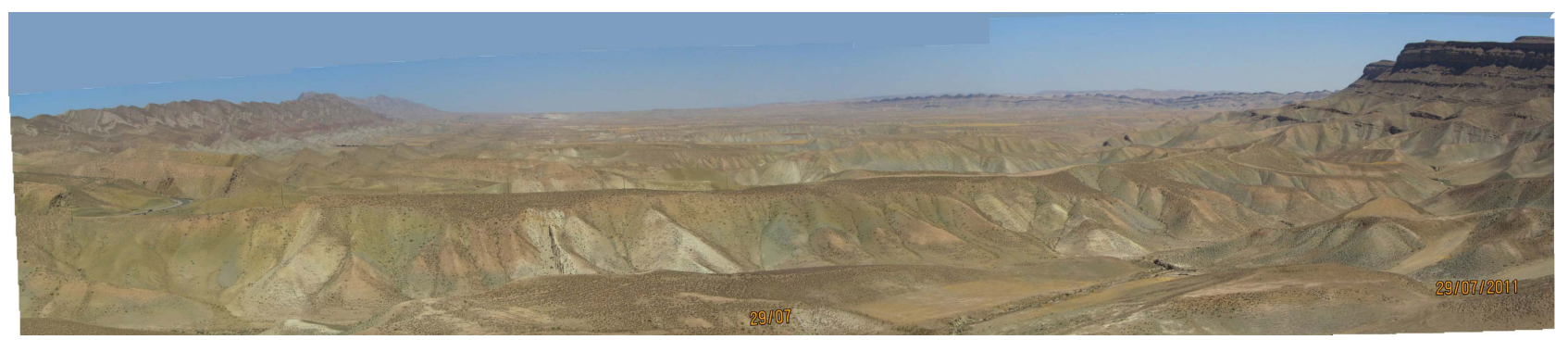

Figure 2. Outline of the study area. 
ever, only 102 materials were studied. After 10 and 25 of the original samples showed traces of dissolution and reworking, respectively. Initially, all the studied samples were compacted and placed in $10 \% \mathrm{H}_{2} \mathrm{O}_{2}$, before being washed through 63 and 125 micron meshes in order to separate sediment and fossils. Samples were placed in an ultrasonic device for approximately 15 minutes. The specimens were then washed and prepared for the reflected-light microscopic analysis. SEM micrographs were taken from the paleontology materials using scanning electron microscopy (SEM) with the Vega TES-CAN device at Razi Metallurgical Institute, Karaj province, Iran (Plate 1). The foraminifera species were identified based on references from books and journal papers from several renowned authors [10-17].

\section{Sea Level Changes}

In spite of the minor palaeoecology importance of planktonic foraminifers, they are useful in palaeoceanographic interpretations of middle and late Cretaceous sequences,

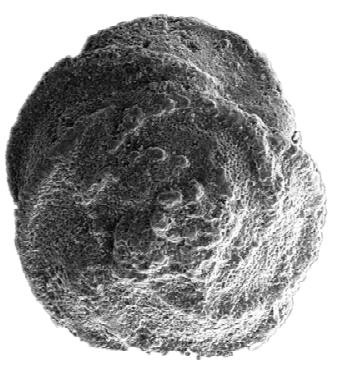

$\Lambda$

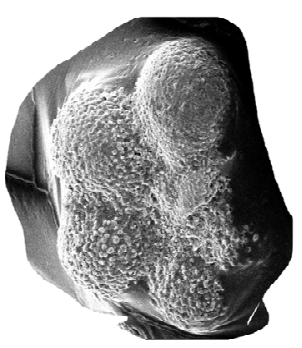

D

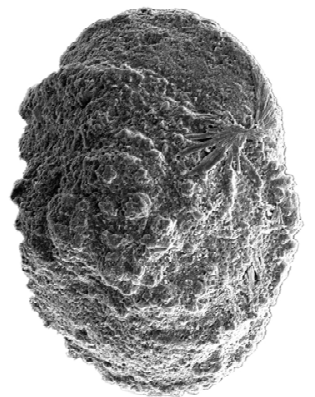

B
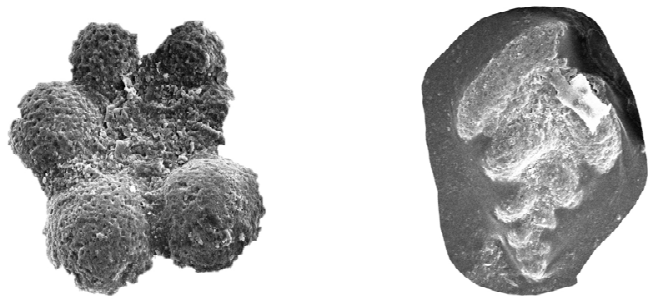

E

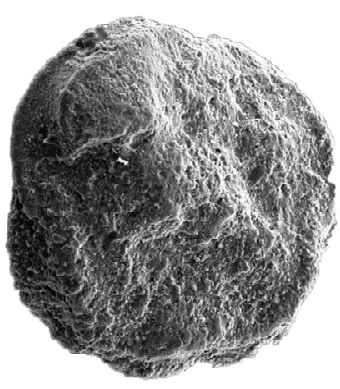

C

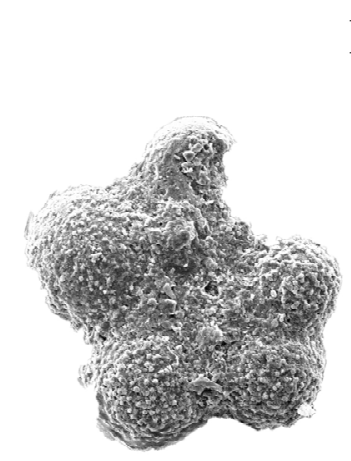

G
F

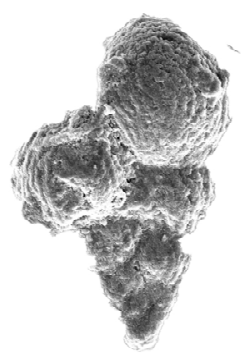

$\mathrm{H}$

Plate 1. (A)-(C) Contusotruncana fornicata, Late Coniacian. Abderaz Formation at type locality; (D) Macroglobigerinelloides bolli, Santonian, Abderaz Formation at type locality; (E) Macroglobigerinelloides sp. Abderaz Formation at type locality; (F) Laeviheterohelix pulchra, Santonian, Abderaz Formation at type locality; (G) Macroglobigerinelloides casey, Abderaz Formation at type locality; (H) Heterohelix globulosa, Late Turonian, Abderaz Formation at type locality; Sclae bar represent 100 $\mu \mathrm{m}$. 
including sea level changes analysis [18]. The estimation of abundance and diversity of planktonic foraminifers and pithonellids is very important in palaeoecology aspects. For instance, Pithonella, an opportunistic genus found in the Tethyan realm, is extremely typical in studying the palaeoceanography of Cretaceous pelagic limestones. Pithonella spherical, a resistant species of pithonellid found in shallow inner neritic waters, was found to be more opportunistic than the other Pithonella species [19].

\section{Results}

The distribution of planktonic foraminifers depends on sea surface water temperature and density. Diverse geometric tests were used to separate and distinguish the specimens found in particular depth ranges within the water column. For instance, deep water planktonic foraminifers are more porous than those living in shallower water zones [3,20-22].

Three groups of planktonic foraminifera were identified on the basis of different depth zones: epicontinental sea forms (ESF), shallow water forms (SWF) and deep water forms (DWF) [20-24]

1) Epicontinental sea forms (ESF)

Species such as Heterohelix and Guembelitria that are associated with this depth zone have straight (bi-/triserial) tests $[3,25]$.

2) Shallow water forms (SWF)

Individuals within this particular depth range have trochospiral and asymmetrical tests with spherical chambers and without any keel. They are either light with a low trim, such as Hedbergella delrioensis [3,25] or have a heavy hispid test, as seen for instance in Whiteinella. Whiteinella baltica is restricted to shallow waters, a fact confirmed by isotopic analysis [26]. However, a large number of small planspiral specimens of Globigerinelloides spp. belong to the epicontinental sea form group [27-29], so are others associated with the two previously-mentioned morphotype groups [30-33].

3) Deep water forms (DWF)

Species associated with this depth zone have asymmetrical trochospiral tests, with either depressed chambers and a primitive keel, such as Praeglobotruncana, or trochospiral with a depressed test and keel, including Marginotruncana spp. [3,25,34,35]. All researches on the Cenomanian-Coniacian transitional boundary revealed that a number of species, including Marginotruncana sinuosa, Heterohelix globulosa, Hedbergella delrioensis and Whiteinella baltica, exhibit dinoflagellate symbiosis and therefore lived in the photic zone [36]. The diversity and frequency of keeled specimens increases from shallow to deeper water [37].

This paper involves only the geometry studies of planktonic foraminifer tests without any isotopic analysis. Therefore, all the individuals that include keeled species were assigned to the deep water form group. In accordance with this method, a total number of 300 specimens taken from each sample included the material processed through both sizes of mesh, with the total number of planktonic and benthic foraminifers therefore 300 for all samples. The abundance of specimens belonging to the epicontinental sea form group, such as Hedbergella delrioensis, Heterohelix globulosa, Heterohelix papula and Globigerinelloides ultramicra, increased towards the base of the Abderaz Formation (i.e. the middle Turonian), indicating the presence of a shallow deposition basin during this time. However, at the end of Turonian, deep water form individuals were also dominant, representing a shift in the planktonic to benthic foraminiferal ratio during this period in relation with middle Turonian. An increase of diversity of the planktonic foraminifers suggests a high quality of habitat. Whereas, a decrease in the diversity of planktonic foraminifers reflects poor life quality of the species of this group. Consequently, it can be inferred that the rising or falling of the sea level, result in a respectively lower or higher population diversity of planktonic foraminifers [38]. Examples of planktonic foraminifera species that occur at this time are including: Marginotruncana sigali, Marginotruncana sinuosa, Marginotruncana schneegansi, Whiteinella brittonensis, Whiteinella aumalensis and Dicarinella canaliculata. This complex assemblage of species represents the result of an increase in water depth during the late Turonian. During the early Coniacian, a decrease in water depth led to an increase of certain biserial planktonic foraminifera belonging to the ESF group, while from the late Coniacian to the early Santonian (i.e. the Coniacian-Santonian transition), an increase in basin depth was associated with the appearance of other planktonic forms, such as Globotruncana and Globotruncanita. These two genera were adapted to moderate depth zones to deep water zones, and geographical localities associated with the tropicalsubtropical Tethyan realm during Cretaceous [39]. Finally, towards the end of the study marine sequence (late Santonian-early Campanian); the water depth was decreasing while the foram groups of heterohelicids and oligosteginids were dominating in the environment. The trends of the curves obtained in this study are based on the analytical methods provided by Leckie (1987) [3]. These trends can also be correlated with the depth curves obtained from the same study data that are referred to the methods from Hart (1980) [1] (Figure 3).

\section{Palaeosalinity}

Planktonic foraminifers are considered as proxies in pa- 


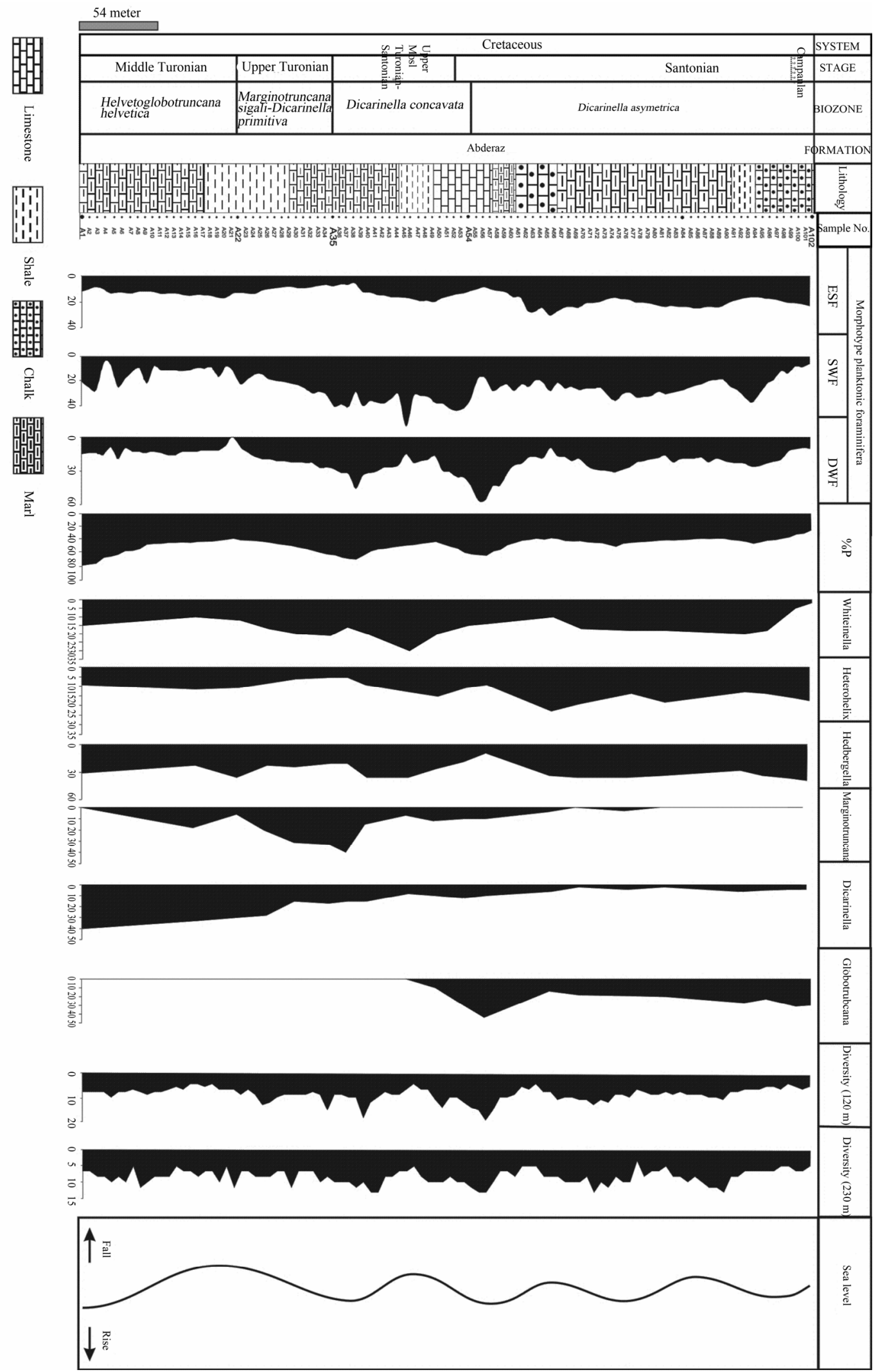

Figure 3. Changes in percentage of the selected planktonic foraminifer genera within the sediments of the Abderaz Formation type section. M1 = epicontinental sea forms (ESF), M2 = shallow water forms (SWF), M3 = deep water forms (DWF), \%p = percentage of planktonic foraminifera (planktonic to benthic foraminifera ratio). 
leosalinity interpretations. Hedbergella spp. and Whiteinella spp. are some of the most typical species that are helpful in interpretations of salinity changes in the ancient marine paleoecosystems [7,8]. For instance, an increase in the relative abundance of Hedbergella planispira represents a decrease in salinity, the arrival of terrestrial sediment and an increase in precipitation in a sedimentary basin. Often, the use of $\delta^{13} \mathrm{C}$ and $\delta^{18} \mathrm{O}$ stable isotope analysis accompanies with such studies [7]. Stable isotope analysis revealed that, Hedbergella planispira was dominant in surface waters [40] of shallow epeiric seas. In the Western Interior seaway, $H$. planispira and low oxygen-tolerant biserial benthic foraminiferal species were alternatively increasing.

$[3,27,28,41]$ (Figure 3). Two of the main Cretaceous planktonic foraminifera species including: Hedbergella delrioensis and Hedbergella simplex, respectively reflected palaeosalinity, and index of surface and subsurface saline environments. In addition, Heterohelix, one of the other Cretaceous biserial planktonic foraminifers, was also representative of palaeosalinity changes.

Heterohelix is known as a high tolerant species against oxygen deficiency or anoxic conditions [41]. In this study which is focused on the Abderaz Formation in the type section, the maximum abundance of Whiteinella and Hedbergella and the minimum number of Heterohelix species within the Coniacian sediments, reflect dwindling palaeosalinity during this time. In contrast, a minimum frequency of Whiteinella and Hedbergella and a maximum number of Heterohelix species was measured in sediments that were deposited in the Coniacian-Santonian transitional boundary. This represents an increase of salinity in the marine environment.

\section{Biogeography}

Throughout the Cretaceous, there were only few geographical gradients from the pole to equator. For example, the northern Atlantic Ocean was separated into two areas of boreal and Tethyan, by a median belt and warm water current $[37,42]$. Some of the genera that were inhabitant of such areas are including: Hedbergella, Globigerinelloides, Heterohelix, Whiteinella, Archaeoglobigerina, Rugoglobigerina and Globotruncanella. Conversely within tethyan areas associated with warm water conditions, planktonic foraminifers were identified which exhibit thick walls and keeled chambers. Examples of such genera include Globotruncana, Globotruncanita, Marginotruncana, Planomalina, Helvetoglobotruncana, Rotalipora, Dicarinella and Contusotruncana. Actually, all comparisons of cool and warm water realms demonstrated a decrease in the number and complexity of species towards the poles (Caron, 1985). Most planktonic foraminifers restricted to warmer waters have larger tests, with thicker walls and a generally more complex morphotype than those found in cool waters. It was proposed that the population of warm water planktonic foraminifers was more diversified than their cool water counterparts [34]. All cool water index species have lefthanded whorls with globular chambers and as a group they have no significant diversification. The first and the last presence of Helvetoglobotruncana helvetica and the last occurrence of Falsotruncana maslakovae are synchronous, occurring during the middle Turonian at a palaeogeographical latitude of between $20 \mathrm{~N}$ and 58S. Both of these species were living in warm water, inhabitants of the Tethyan realm, with a maximum temperature of $30^{\circ} \mathrm{C}$. In contrast, Dicarinella asymetrica, that was dominant during Santonian to early Campanian at palaeolatitudes between $20 \mathrm{~N}$ and $47 \mathrm{~S}$, was restricted to deep and oligotrophic to mezotrophic marine conditions $[25,43,44]$. Briefly, we may conclude that, the identified planktonic foraminifers within the sediments of the Abderaz Formation represent a warm water seaway in connection with the Tethyan realm during Upper Cretaceous (Table 1).

The frequency analysis of some planktonic foraminifera species within the sediments of Abderaz Formation, such as H. globulosa, H. delrioensis, M. peudolinneiana, M. marginata, D. canaliculata, A. cretacea, H. planispira, G. bulloides, M. renzi, D. concavata, D. asymetrica and G. Linneiana, suggests that these species were more resistant to such environmental changes than the other planktonic species (including: $P$. delrioensis, $C$. pateliformis, G. elevata, H. carinata, S. multispinata and G. cretacea).

Table 1. The paleobiogeographic classification of planktonic foraminifers.

\begin{tabular}{ccr}
\hline Cold water fauna & Warm water fauna & $\begin{array}{c}\text { Some planktonic genera } \\
\text { at studied area }\end{array}$ \\
\hline Archaeoglobigerina & Dicarinella & Dicarinella \\
Globigerinelloides & Globotruncana & Globotruncana \\
Heterohelix & Globotruncanita & Globotruncanita \\
Hedbergella & Marginotruncana & Hedbergella \\
Whiteinalla & Helvetoglobotruncana & Helvetoglobotruncana \\
& & \\
& Planomalina & Marginotruncana
\end{tabular}




\section{Conclusions}

The study of planktonic foraminifers in the Abderaz Formation revealed three swarming morphotypes: epicontinental sea forms (ESF), shallow water forms (SWF) and deep water forms (DWF). Integration of the palaeontology study of these planktonic morphotypes with some statistical calculations reflects a shallow water realm during the middle Turonian, followed by deep water conditions across the sedimentary basin in the late Turonian. The Coniacian settings were characterised by dominant shallow water with less than $100 \mathrm{~m}$ depth, whereas, towards the Coniacian-Santonian transitional boundary, deeper water conditions were dominant within the sedimentary basin. Finally, the uppermost sediments of the last marine sequence (late Santonian-early Campanian) of the Abderaz Formation represent a dominant shallow water regime during late Cretaceous.

These regressive cycles are reflected by the planktonic to benthic foraminifera ratio and also the three morphotype groups of the planktonic foraminifers. The numbers of Whiteinella spp. and Hedbergella spp. in palaeosalinity estimations were the minimum during the Coniacian and a maximum at the Coniacian-Santonian boundary. The similarities of the planktonic foraminifers from the study section with the species from the other palaeobiogeographical provinces during Cretaceous period, and the frequency of some species in the Abderaz Formation, including: Helvetoglobotruncana, Dicarinella, Marginotruncana, Globotruncana and Contusotruncana, proved that the study area shares similar faunal and biogeography characteristics with the Tethyan realm.

\section{Acknowledgements}

We are grateful to Ferdowsi University of Mashhad for the financial supports of this research. We would also like to thank Ferdowsi University of Mashhad, for providing us with scanning electron microscope (SEM) analysis. Also the authors would like to express his deep gratitude Dr. Rahimi-Nejad, for their invaluable helps during the study.

\section{REFERENCES}

[1] M. S. Ardestani, E. Ghasemi-Nejad and H. Vazirimoghadam, "Palaeobathymetry of the Abderaz Formation at Type Section Using Planktonic and Benthic Foraminifera," Journal of Science University of Tehran, Vol. 34, No. 4, 2008, pp. 45-57. (in Persian, abstract in English)

[2] M. B. Hart, "The Recognition of Mid-Cretaceous Sea Level Changes by Means of Foraminifera," Cretaceous Research, Vol. 1, No. 4, 1980, pp. 289-297. doi:10.1016/0195-6671(80)90040-3
[3] R. M. Leckie, "Paleoecology of Mid-Cretaceous Planktonic Foraminifera: A Comparison of Open Ocean \& Epicontinental Sea Assemblages,” Micropaleontology, Vol. 33, No. 2, 1987, pp. 164-176. doi:10.2307/1485491

[4] F. J. Jorissen, C. Fontanier and E. Thomas, "Paleoceanographical Proxies Based on Deep-Sea Benthic Foraminiferal Assemblage Characteristics," Developments in Marine Geology, Vol. 1, 2007, pp. 263-325. doi:10.1016/S1572-5480(07)01012-3

[5] F. B. Phleger, "Foraminiferal Distribution, Pt. l, Ecology of Foraminifera, Northwest Gulf of Mexico," The Geological Society of American Memoir, Vol. 46, 1951, pp. 1-88.

[6] T. F. Grimsdale and F. P. C. M. Van Morkhoven, "The Ratio between Pelagic \& Benthonic Foraminifera as a Means of Estimating Depth of Deposition of Sedimentary Rocks," Proceedings of the 4th World Petroleum Congress (Rome) Section 1/D4, Rome, 1955, pp. 473-491.

[7] T. Wolff, B. Grieger, W. Hale, A. Dürkoop, S. Mulitza, J. Pätzold and G. Wefer, "On the Reconstruction of Paleosalinites,” In: G. Fischer and G. Wefer, Eds., Use of Proxies in Paleoceanography: Examples from the South Atlantic, Springer-Verlag, Berlin, 1999, pp. 207-228. doi:10.1007/978-3-642-58646-0_8

[8] C. Pierre, "The Carbon \& Oxygen Isotope Distribution in the Mediterranean Water Masses,” Marine Geology, Vol. 153, No. 1-4, 1999, pp. 41-55. doi:10.1016/S0025-3227(98)00090-5

[9] A. Afshar-Harb, “Geology of Kopet Dagh.,” In: A. Hushmandzadeh, Ed., Treatise on the Geology of Iran, Geological Survey of Iran, Tehran, 1994. (in Persian)

[10] H. M. Bolli, “The Genera Praeglobotruncana, Globotruncana, Rotalipora Abathomphalus in the Upper Cretaceous of Trinidad,” Natural History Museum Bulletin, Vol. 1, No. 215, 1957, pp. 51-60.

[11] J. Postuma, "Manual of Planktonic Foraminifera,” Elsevier Publishing Co., Amsterdam, 1971.

[12] F. Robaszynski and M. Caron, "Atlas de Foraminife`rs Planctoniques du Cre'tace' Moyen (Mer Boreale et Tethys), Premie re Partie,” Cahiers de Micropaleontologie, Vol. 1, No. 15, 1979, pp. 1-185.

[13] F. Robaszynski and M. Caron, "Foraminifers Planktonique du Cretace," Bulletine Society Geological of France, Vol. 166, 1995, pp. 681-698.

[14] I. P. Silva and W. V. Sliter, "Cretaceous Planktonic Foraminiferal Biostratigraphy \& Evolutionary Trends from the Bottaccione Section, Gubbio, Italy,” Palaeontographia Italica, Vol. 82, 1994, pp. 1-89.

[15] A. R. Loeblich Jr and E. Tappan, "Foraminiferal Genera \& Their Classification,” Van Nostrand Reinhold Company, New York, 1988.

[16] B. F. Ellis and A. R. Messina, "Catalogue of Foraminifera on CD ROM,” American Museum of Natural History, New York, 1999.

[17] I. P. Silva and D. Verga, "Practical Manual of Cretaceous Planktonic Foraminifera,” In: D. Verga and R. Rettori, 
Eds., International School on Planktonic Foraminifera, Universities of Perugia \& Milano, Tipografia Pontefelcino, Perugia, 2004.

[18] M. B. Hart and D. J. Carter, "Some Observation on the Cretaceous Foraminifera of South-East England,” Journal of Foraminiferal Research, Vol. 5, No. 2, 1975, pp. 114126.

[19] D. Dias-Brito, “Global Stratigraphy, Palaeobiogeography \& Palaeoecology of Albian-Maastrichtian Pithonellid Calcispheres," Cretaceous Research, Vol. 21, No. 2-3, 2000, pp. 315-349. doi:10.1006/cres.2000.0196

[20] G. Keller, T. Adatte, W. Stinnesbeck, V. Luciani, N. Karoui and D. Zaghbib-Turki, "Tertiary Mass Extinction in Planktic Foraminifera,” Palaeogeography, Palaeoclimatology, Palaeoecology, Vol. 178, No. 3-4, 2002, pp. 257-298. doi:10.1016/S0031-0182(01)00399-6

[21] R. Martinez, "Foraminiferal Biostratigraphy \& Paleoenvironment of the Mastrichtian Colon Mudstone of Northern South America,” Micropaleontology, Vol. 35, No. 2, 1989, pp. 97-113. doi:10.2307/1485462

[22] V. Luciani, "High Resolution Planktonic Foraminifera Analysis from the Cretaceous-Tertiary Boundary at Ain Settara (Tunisia): Evidence of an Extended Mass Extinction," Palaeogeography, Palaeoclimatology, Palaeoecology, Vol. 178, No. 3-4, 2002, pp. 299-319. doi:10.1016/S0031-0182(01)00400-X

[23] A. Shahin, "Contribution to the Foraminifera Biostratigraphy \& Paleobathymetry of the Late Cretaceous \& Early Tertiary in Western Central Sinai Egypt," Revue de Micropaleontologie, Vol. 35, No. 2, 1992, pp. 157-175.

[24] D. Schmidt, H. Thierstein and G. Bollmann, “The Evolutionary History of Size Variation of Planktonic Foraminifera Assemblage in the Cenozoic,” Palaeogeography, Palaeoclimatology, Palaeoecology, Vol. 212, No. 1, 2004, pp. 159-180.

[25] I. P. Silva and W. V. Sliter, "Cretaceous Paleoceanography: Evidence from Planktonic Foraminiferal Evolution,” The Geological Society of America, Vol. 332, 1999, pp. 301-328.

[26] M. B. Hart, "The Evolution and Biodiversity of Cretaceous Planktonic Foraminiferida,” Geobios, Vol. 32, No. 2, 1999, pp. 247-255. doi:10.1016/S0016-6995(99)80038-2

[27] D. L. Eicher, "Cenomanian \& Turonian Planktonic Foraminifera from the Western Interior of the United States,” In: P. Bronnimann and H. H. Renz, Eds., Proceedings of the First International Conference on Planktonic Microfossils, E.J. Brill, Leiden, 1969a, pp. 163-174.

[28] D. L. Eicher and P. Worstell, "Cenomanian \& Turonian, Foraminifera from the Great Plains, United States," Micropaleontology, Vol. 16, No. 3, 1970, pp. 296-324. doi: $10.2307 / 1485079$

[29] W. V. Sliter, "Upper Cretaceous Planktonic Foraminiferal Zoogeography \& Ecology-Eastern Pacific Margin,” Palaeogeography, Palaeoclimatology, Palaeoecology, Vol. 12, No. 12, 1972, pp. 15-31.
[30] H. Tappan, "Foraminifera from Thengrayson Formation of Northern Texas,” Journal of Paleontology, Vol. 14, No. 2, 1940, pp. 93-126.

[31] H. Tappan, "Foraminifera from the Duck Creek Formation of Oklahoma \& Texas,” Journal of Paleontology, Vol. 17, No. 5, 1943, pp. 93-126.

[32] A. R. Loeblich Jr. and H. Tappan, "Foraminifera from the Type Kiowa Shale, Lower Cretaceous of Kansas,” University of Kansas, Lawrence, 1950.

[33] D. L. Eicher, “Cenomanian \& Turonian Planktonic Foraminifera from the Western Interior of the United States,” In: P. Bronnimann and H. H. Renz, Eds., Proceedings of the First International Conference on Planktonic Microfossils, E.J. Brill, Leiden, Vol. 2, 1969b, pp. 163174.

[34] M. Caron and P. Homewood, "Evolution of Early Planktic Foraminifers,” Marine Micropaleontology, Vol. 7, No. 6, 1983, pp. 435-462. doi:10.1016/0377-8398(83)90010-5

[35] P. N. Leary and M. B. Hart, "The Use of Ontogeny of Deep Water Dwelling Planktic Foraminifera to Assess Basin Morphology, the Development of Water Masses, Eustasy and the Position of the Oxygen Minimum Zone in the Water Column,” Mesozoic Research, Vol. 2, No. 2, 1989, pp. 67-74.

[36] C. Emiliani, “Pleistocene Temperatures,” The Journal of Geology, Vol. 63, No. 6, 1955, pp. 538-578. doi:10.1086/626295

[37] R. G. Douglas and W. V. Sliter, "Regional Distribution of Late Cretaceous Rotaliporidae \& Globotruncanidae (Foraminiferida) within North America,” Tulane Stude in Geology, Vol. 4, No. 3, 1966, pp. 89-131.

[38] G. Ottens and A. Nederbragt, "Planktonic Foraminifer's Diversity as Indicator of Ocean Environment," Marine Micropaleontology, Vol. 19, No. 1-2, 1992, pp. 13-28. doi:10.1016/0377-8398(92)90019-G

[39] S. Abramovich, G. Keller, T. Adatte, W. Stinnesbeck, L. Hottinger, D. Stueben, Z. Berner, B. Ramanivosoa and A. Randriamanan Tenasoa, “Age \& Paleoenviroment of the Maastrichtian to Paleocene of the Mahajanga Basin, Madagascar: A Multidisciplinary Approach,” Marine Micropaleontology Vol. 47, No. 1-2, 2002, pp. 17-70.

[40] G. D. Price and M. B. Hart, "Isotopic Evidence for Early to Mid-Cretaceous Ocean Temperature Variability,” Marine Micropaleontology, Vol. 46, No. 1-2, 2002, pp. 4558. doi:10.1016/S0377-8398(02)00043-9

[41] G. Keller and A. Pardo, "Paleoecology of the Cenomanian-Turonian Stratotype Section (GSSP) at Pueblo, Colorado," Marine Micropaleontology, Vol. 51, No. 1-2, 2004, pp. 95-128. doi:10.1016/j.marmicro.2003.08.004

[42] H. W. Bailey and M. B. Hart, "The Correlation of the Early Santonian in Western Europas,” IUGS, Vol. 1, No. 6, 1979, pp. 159-169.

[43] M. Caron, “Cretaceous Planktic Foraminifera,” In: H. M. Bolli, J. B. Saunders and K. P. Nielsen, Eds., Plankton Stratigraphy, Cambridge University Press, Cambridge, 1985, pp. 17-86. 
[44] M. R. Petrizzo, "Palaeoceanographic \& Palaeoclimatic Inferences from Late Cretaceous Planktonic Foraminiferal Assemblages from the Exmouth Plateau (ODP Sites
762 and 763, Eastern Indian Ocean),” Marine Micropaleontology, Vol. 45, No. 2, 2002, pp. 117-150.

doi:10.1016/S0377-8398(02)00020-8 